\title{
TELMATOBLECHNUM (BLECHNACEAE): A NEW GENUS FOR THE URUGUAYAN FLORA
}

\author{
Andrés González ${ }^{1}$ (iD, Vinicius A. O. Dittrich² (iD) \& Marcelo D. Arana ${ }^{3}$ (iD
}

\begin{abstract}
${ }^{1}$ Departamento de Botánica, Museo Nacional de Historia Natural, CP 11000, Montevideo, Uruguay.
${ }^{2}$ Departamento de Botânica, Instituto de Ciências Biológicas, Universidade Federal de Juiz de Fora, Rua José Lourenço Kelmer, s/n-Campus Universitário, Bairro São Pedro, 36036-900, Juiz de Fora, MG, Brazil.

${ }^{3}$ Orientación Plantas Vasculares, Departamento de Ciencias Naturales, Facultad de Ciencias Exactas, Físico-Químicas y Naturales, Instituto ICBIA (UNRC-CONICET), Universidad Nacional de Río Cuarto, Ruta $36 \mathrm{~km}$ 601, X5804ZAB Río Cuarto,Córdoba, Argentina; marana@exa.unrc.edu.ar (author for correspondence).
\end{abstract}

\begin{abstract}
González, A.; V. A. O. Dittrich \& M. D. Arana. 2020. Telmatoblechnum (Blechnaceae): a new genus for the Uruguayan flora. Darwiniana, nueva serie 8(2): 525-529.

Telmatoblechnum, with the species Telmatoblechnum serrulatum (Blechnaceae), is recorded for the first time for the Uruguayan flora. The species, so far known from southern Brazil and Northeastern Argentina as its southernmost distribution limit, was collected for the first time in crevices between rocks of basalt and sandstone in a small hill in Uruguay (Rivera). Its morphological characteristics and the novel habitat for the species are included; photographs, a map with the location of the new record, as well as a key to the genera of Blechnaceae in Uruguay are provided.
\end{abstract}

Keywords. Polypodiales; Stenochlaenoideae; Telmatoblechnum; Uruguayan flora.

Resumen. González, A.; V. A. O. Dittrich \& M. D. Arana. 2020. Telmatoblechnum (Blechnaceae): un nuevo género para la flora uruguaya. Darwiniana, nueva serie 8(2): 525-529.

Telmatoblechnum, con la especie Telmatoblechnum serrulatum (Blechnaceae), es registrado por primera vez para la flora uruguaya. La especie, conocida hasta ahora para el sur de Brasil y noreste de Argentina como su límite sur de distribución, fue colectada por primera vez en hendiduras entre rocas de basalto y arenisca en un pequeño cerro en Uruguay (Rivera). Se incluyen sus características morfológicas y el hábitat novedoso para la especie; se presentan además fotografías, un mapa con la localización del nuevo registro, así como una clave para los géneros de Blechnaceae en Uruguay.

Palabras claves. Flora uruguaya; Polypodiales; Stenochlaenoideae; Telmatoblechnum.

\section{INTRODUCTION}

The Blechnaceae is a monophyletic family of leptosporangiate ferns that comprises 250-265 species distributed worldwide (PPG I, 2016), but most of the diversity occurs in the Southern Hemisphere, primarily in tropical and subtropical ecosystems, but extending also to temperatecold habitats (Rothfels et al., 2012), with the main centres of diversity and endemism in the Neotropics and the Australasia/Oceania region (Dittrich et al., 2007). The plants grouped in Blechnaceae are mostly terrestrial herbs, sometimes rheophytic, aquatic, arborescent, scandent, or even epiphytic, but rarely truly aquatic. Traditionally, the family contained 9-10 genera, with the large genus Blechnum L. comprising almost $80 \%$ of the diversity, but recent studies have demonstrated the paraphyly of the genus Blechnum sensu lato (Shepherd et al., 2007; Gabriel y Galán et al., 2013; Perrie et al., 2014; Gasper et al., 2017). As a result, the genus has been split into several entities, and a total of 24 genera have been recognized in Blechnaceae (Gasper et al., 2016; PPG I, 2016), criteria followed by the Flora del Cono Sur (Southern Cone flora project, 
Zuloaga et al., 2019). With the further recognition of Spicantopsis Nakai by Molino et al. (2019), 25 genera are now recognized in the family.

One of the lineages recognized to genus level is Telmatoblechnum Perrie, D.J. Ohlsen \& Brownsey, included in the subfamily Stenochlaenoideae (Ching) J.P. Roux, and characterized by long-creeping rhizomes, covered with bicolorous, lanceolate, entire scales; fronds monomorphic to slightly dimorphic (in T. indicum (Burm. f.) Perrie, D.J. Ohlsen \& Brownsey, with pinnae of fertile fronds slightly smaller), with pinnae articulate to rachises and margins serrate, veins free, 1-3-forked, ending at the pinna margins; sori linear, close to costae, with narrow indusia, margins erose or lacerate. The genus includes just two species which often grow in humid places as swamps, with their rhizomes and lower parts of fronds under water, or humid savannas. The species Telmatoblechnum indicum grows in Thailand, Malaysia, Indonesia, Papua New Guinea, Australia, Vanuatu, and New Caledonia (Perrie et al., 2014), whereas Telmatoblechnum serrulatum (Rich.) Perrie, D.J. Ohlsen \& Brownsey has an American distribution, with its southernmost limit in southern Brazil and northeastern Argentina. Recent botanical explorations in Uruguay allowed the discovery of a population of $T$. serrulatum growing in crevices between rocks of basalt and sandstone in a small hill. This finding constitutes the first record of the genus for the Uruguayan flora and a novel habitat for the species. In this work we present a description of the species and its habitat in Uruguay, as well as photographs and a map with the location of the new record. Also, a key to the genera of Blechnaceae in Uruguay is provided.

\section{MATERIAL AND METHODS}

This study is based on vouchers collected in the Department of Rivera and kept in MVM herbarium (abbreviation according to Thiers, 2020). Also, specimens from mainly Argentinian, Brazilian and Uruguayan herbaria (BA, CTES, JUA, LIL, LP, MA, MERL, MCNS, MERL, MVJB, MVFA, MVM, $\mathrm{RB}, \mathrm{RCVC}$, SI and SRFA) plus observations of the plants in nature were carried out. The specimens were identified using regional floras such as Ramos Giacosa (2016) and Dittrich et al. (2017).

\section{RESULTS}

Telmatoblechnum serrulatum (Rich.) Perrie, D.J. Ohlsen \& Brownsey, Taxon 63: 755. 2014. $\equiv$ Blechnum serrulatum Rich., Actes Soc. Hist. Nat. Paris 1: 114. 1792. EBlechnopsis serrulata (Rich.) C. Presl, Epim. Bot.: 119. 1851. 三Spicanta serrulata (Rich.) Kuntze, Rev. Gen. P1. 2: 821. 1891. TYPE: French Guiana. Without date, J. B. Le Blond s.n. (holotype P00627607! (Herbarium Richard)). Fig. 1.

Plants terrestrial; rhizomes long-creeping, subterranean, the scales tan, each with a dark central stripe, lanceolate, $2.5-3 \mathrm{~mm}$ long, margins entire; fronds monomorphic, $12-90 \mathrm{~cm}$ long; stipes stramineous, slightly compressed, ridged adaxially, the scales at bases similar to those on rhizomes; blades oblong to lanceolate, chartaceous to coriaceous, pinnate, glabrous except abaxially on costae, at the apices reduced to an apical pinna smaller than the lateral ones, truncate at the bases; rachises glabrous or with amorphous scales typically less than $1 \mathrm{~mm}$ long, light, hyaline; pinnae 13-25 pairs, sessile, articulate to rachises, linear or linear-oblong, ascending, rarely patent, margins serrate, apices acute to acuminate, with light tan, ovate-acuminate scales on the costa abaxially; veins free, simple or 1-2 forked, vein ends not enlarged, terminating at the margins. Indusia with entire or erose margins. Spores smooth with numerous superficial globules.

Distribution and habitat. USA, Mexico, Guatemala, Belize, Honduras, El Salvador, Nicaragua, Costa Rica, Panama, Greater and Lesser Antilles, Trinidad \& Tobago, Guyana, Suriname, French Guiana, Colombia, Venezuela, Ecuador, Peru, Bolivia, Brazil, Paraguay, northeast Argentina, and (here cited for the first time; Fig. 2) Uruguay.

This species has been registered to occur in open areas, such as grasslands (waterlogged or not) and disturbed habitats as road margins, generally in sandy, poor soils, and less frequently in forested areas. In the study area, Telmatoblechnum serrulatum occurs in a small hill made up of sandstone and large blocks of basalt. The species grows in sunny crevices between the basalt, which constitutes a novel habitat for the species. 
Comments. In the Neotropics, this is the only genus of Blechnaceae with pinnae articulate to rachis. According to Moran (1995), the pinnae abscise completely in regions with a marked dry season, leaving the rachises naked. This phenomenon was also observed by us in Brazilian Atlantic forest, in habitats without marked dry season. In the study area, it can be distinguished from all other species of the family with monomorphic fronds by the articulate pinnae with serrulate margins.

According to Brussa \& Grela (2005) and Zuloaga et al. (2019), there are 130 species of Lycopodiopsida and Polypodiopsida in Uruguay. With this study, nine taxa of Blechnaceae are recognized for Uruguay under the following genera: Austroblechnum Gasper \& V.A.O. Dittrich, Blechnum, Lomaridium C. Presl, Lomariocycas (J. Sm.) Gasper \& A.R. Sm.,
Neoblechnum Gasper \& V.A.O. Dittrich, Parablechnum C. Presl and Telmatoblechnum, being Blechnum the most diverse genus.

\section{Representative specimens examined}

ARGEnTINA. Chaco. Depto. Primero de Mayo, Planta de 50-70 $\mathrm{cm}$ de altura, en los esteros, entre juncos, XII-1929, A. G. Schulz 9 (SI). Corrientes. Depto. Santo Tomé, embalsado, abundante, 25-IV-1995, M. M. Arbo 6551 (SI). BRAZIL. Santa Catarina. Itajaí, Escalvado, 20 m, 20-IV-1946, R. Reitz C1582 (RB); Balneário Camboriú, 17-I-2011, M. D. Arana s.n. (RCVC). URUGUAY. Depto. Rivera: en fisuras entre bloques de basalto y arenisca en cerro chato "Piedra de Oro", camino a Arroyo Sauzal, 3056'11.33”S, 55³6’42.59”'W, 2-II-2020, J. Antúnez y A. González s.n. (MVM 23487).
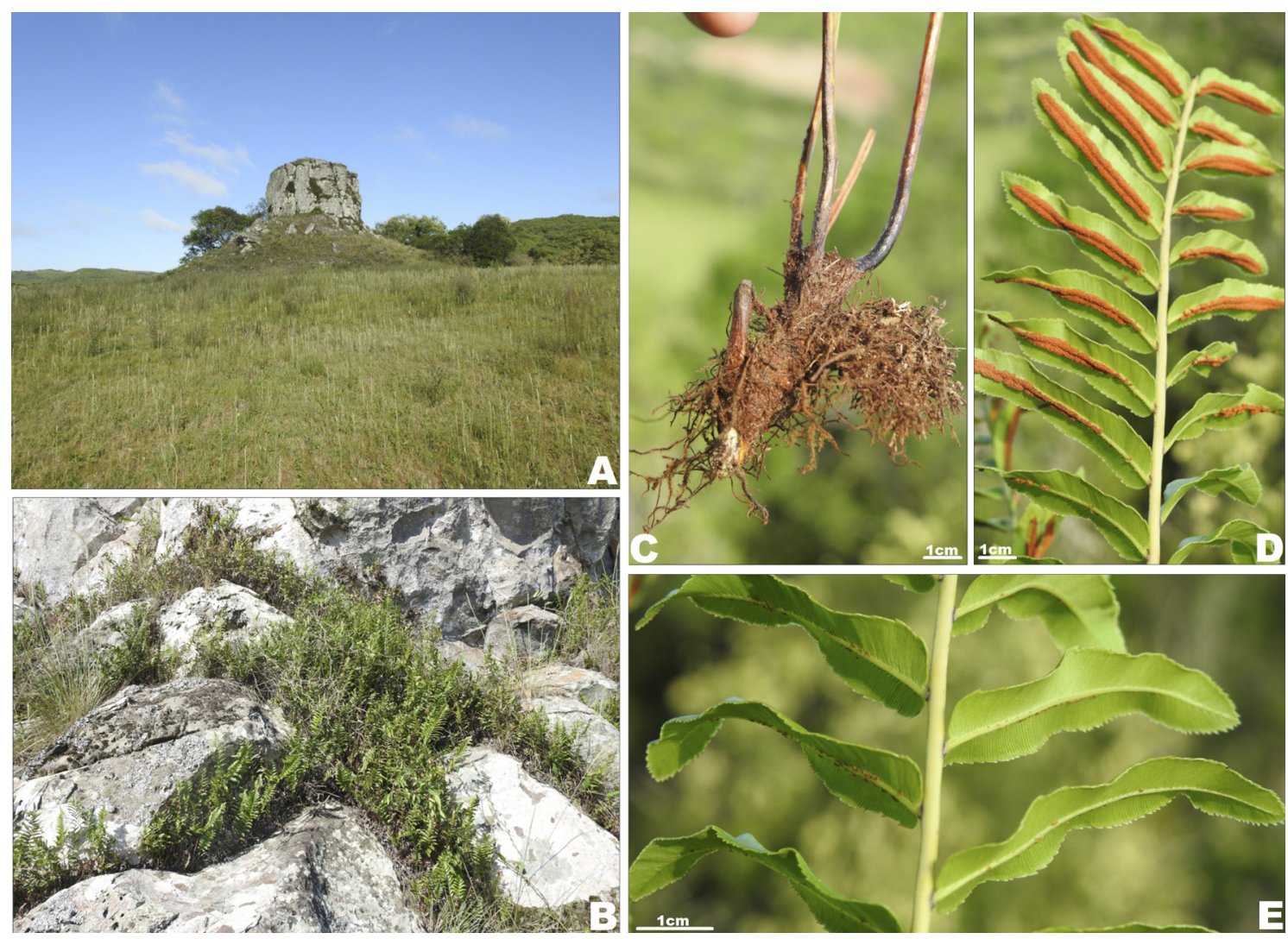

Fig. 1. Telmatoblechnum serrulatum. A, habitat, "Piedra de Oro" Hill, Rivera department. B, population of Telmatoblechnum serrulatum showing the novel habitat. C, rhizome. D, fertile frond showing sori. E, sterile frond. Color version at http:// www.ojs.darwin.edu.ar/index.php/darwiniana/article/view/920/1198 


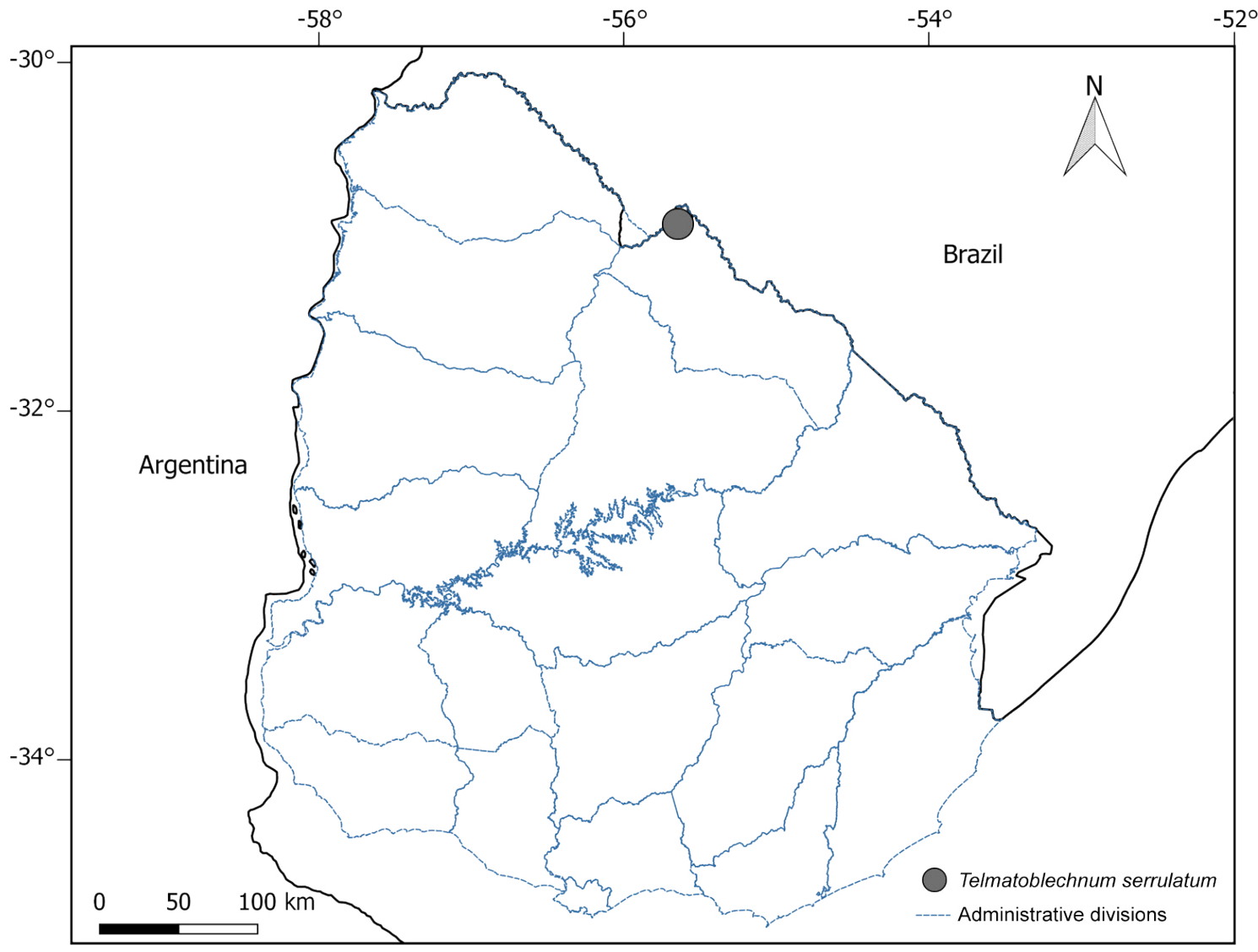

Fig. 2. Distribution map of Telmatoblechnum serrulatum in Uruguay.

\section{Key to the Uruguayan genera of Blechnaceae}

1. Sterile and fertile fronds monomorphic or slightly dimorphic 2

1. Sterile and fertile fronds clearly dimorphic

2. Fronds never fully pinnate, just pinnatifid to pinnatisect; pinnae not articulate to rachises 3

3(2). Leaf margins serrulate Neoblechnum

3. Leaf margins entire or nearly so, never serrulate Blechnum 4(1). Rhizome long-creeping with scales generally denticulate, plants generally hemiepiphytic

Lomaridium

4. Rhizome erect to short-creeping with scales entire, plants never hemiepiphytic or epiphytic 5 5(4). Pinnae adnate throughout Austroblechnum

5. Pinnae (at least the basal ones) not adnate, sessile or stalked 6 6(5). Leaf blades truncate at base Parablechnum

6 . Pinnae gradually reduced towards the base of the blade Lomariocycas 


\section{A. GONZÁLEZ ET AL. Telmatoblechnum in Uruguay}

\section{ACKNOWLEDGEMENTS}

The authors thank José Luis Antúnez for his collaboration in the collection trips and hospitality. We also want to thank to editor Mónica Ponce, Fernando Biganzoli and two revisors for their accurate observations that helped to improve the manuscript.

\section{REFERENCES}

Brussa, C. A. \& I. Grela. 2005. Revisión taxonómica de Pteridophyta en Uruguay. Boletín de la Sociedad Argentina de Botánica (Suplemento) 40: 193.

Dittrich, V. A. O.; G. Heringer \& A. Salino. 2007. Blechnaceae. In: Cavalcanti, T. B., Ramos, A. E. (Eds.) Flora do Distrito Federal. Embrapa Recursos Genéticos e Biotecnologia, Brasília. pp. 91-108.

Dittrich, V. A. O.; A. Salino, R. Monteiro \& A. L. de Gasper. 2017. The family Blechnaceae (Polypodiopsida) in Brazil: key to the genera and taxonomic treatment of Austroblechnum, Cranfillia, Lomaridium, Neoblechnum and Telmatoblechnum for southern and southeastern Brazil. Phytotaxa 303 (1): 1-33. DOI: https://doi.org/10.11646/phytotaxa.303.1.1

Gabriel y Galán, J. M.; C. Prada, C. Rolleri, A. Ainouche \& M. Vicent. 2013. cpDNA supports the identification of the major lineages of American Blechnum (Blechnaceae, Polypodiopsida) established by morphology. Turkish Journal of Botany 37: 769-777.

Gasper, A. L. de; T. E. Almeida, V. A. O. Dittrich, A. R. Smith \& A. Salino. 2017. Molecular phylogeny of the fern family Blechnaceae (Polypodiales) with a revised genus-level treatment. Cladistics 33(4): 429-446. DOI: http://dx.doi. org/10.1111/cla.12173

Gasper, A. L. de; V. A. O. Dittrich, A. R. Smith \& A. Salino. 2016. A classification for Blechnaceae (Polypodiales: Polypodiopsida): New genera, resurrected names, and combinations. Phytotaxa 275(3): 191-227. DOI: http:// dx.doi.org/10.11646/phytotaxa.275.3.1

Molino, S.; J. M. Gabriel y Galán, E. B. Sessa \& P. Wasowicz. 2019. A multi-character analysis of Struthiopteris leads to the rescue of Spicantopsis (Blechnaceae, Polypodiopsida). Taxon 68 (2): 185-198.

Moran, R. C. 1995. Blechnaceae. In: Davidse, G.; M. Sousa \& S. Knapp (Eds.). Flora Mesoamericana, V. 1: Psilotaceae a Salviniaceae. Universidad Nacional Autónoma de México, Ciudad de México, pp. 325-333.

Perrie, L. R.; R. K. Wilson, L. D. Shepherd, D. J. Ohlsen, E. L. Batty, P. J. Brownsey \& M. J. Bayly. 2014. Molecular phylogenetics and generic taxonomy of Blechnaceae ferns. Taxon 63 (4): 745-758. DOI: http://dx.doi. org $/ 10.12705 / 634.13$

PPG I. 2016. A community-derived classification for extant lycophytes and ferns. Journal of Systematics and Evolution 54: 563-603. DOI: http://dx.doi.org/10.1111/jse.12229

Ramos Giacosa, J. P. 2016. Blechnaceae, in M. M. Ponce \& M. D. Arana (coords.). Flora Argentina 2: 86-104.

Rothfels, C. J.; M. A. Sundue, L. -Y. Kuo, A. Larsson, M. Kato, E. Schuettpelz \& K. M. Pryer. 2012. A revised familylevel classification for eupolypod II ferns (Polypodiidae: Polypodiales). Taxon 61: 515-533. DOI: http://dx.doi. org/10.1093/sysbio/sys001

Shepherd, L. D.; L. R. Perrie, B. S. Parris \& P. J. Brownsey. 2007. A molecular phylogeny for the New Zealand Blechnaceae ferns from analyses of chloroplast trnL-trnF DNA sequences. New Zealand Journal of Botany 45: 67-80. DOI: http://dx.doi.org/10.1080/00288250709509703

Thiers, B. [consulted 2020] Index Herbariorum: a global directory of public herbaria and associated staff. New York Botanical Garden's Virtual Herbarium, http://sweetgum. nybg.org/ih

Zuloaga, F. O.; M. J. Belgrano \& C. A. Zanotti. 2019. Actualización del Catálogo de las Plantas Vasculares del Cono Sur. Darwiniana, nueva serie 7: 208-278. 